\title{
Simple control scheme buck-boost DC-DC converter for stand alone PV application system
}

\author{
M. Z. Zulkifli, M. Azri, A. Alias, N. Talib, J. M. Lazi \\ Center for Robotics and Industrial Automation (CeRIA), Fakulti Kejuruteraan Elektrik, \\ Universiti Teknikal Malaysia Melaka, Malaysia
}

\section{Article Info \\ Article history: \\ Received Jul 19, 2018 \\ Revised Dec 6, 2018 \\ Accepted Mar 3, 2019}

\section{Keywords:}

Buck-boost

Charging management

Control methods

Converter

PV system

\begin{abstract}
In this paper a buck-boost dc-dc converter for pv application is proposed, which is mainly composed of a buck-boost converter, PV panel, load and a battery. Existing dc-dc converter can convert the power from the PV panel, but unfortunately the PV panel can only provide power when there is a high intensity of light. In order to provide power supply to the load without any interruption, buck-boost DC-DC converter is introduced. The power intermittency issue of PV panel can be overcome with the aid of a secondary supply which is in this case, the batter. The integration system between the primary and the secondary supply is controlled by a simple proposed control scheme. Battery act as a power in the low voltage side while PV panel is taking over in the high voltage side. Buck-boost converter is operated either is buck or boost mode according to the performance of the PV panel. This paper is presented the simple control scheme to decide the mode suitable for the buck and boost mode. Various conditions are simulated to verify the working operation of the buck-boost converter and to representing solar panel in real life. Simulation and experimental are carried out to verify the system.
\end{abstract}

Copyright (C) 2019 Institute of Advanced Engineering and Science. All rights reserved.

\section{Corresponding Author:}

Mohamad Zaki Bin Zulkifli, Faculty of Electrical Engineering, Universiti Teknikal Malaysia Melaka, Jalan Hang Tuah Jaya, 76100 Durian Tunggal Melaka.

Email:m011810006@student.utem.edu.my

\section{INTRODUCTION}

Power converters is one of the most important parts in photovoltaic system. The reason that they play an important role as they can convert the different type of electricity and make the electricity convenient to the end user. Since the solar cells produces DC type of electricity, there is room for various types of power converter [1]. Because of constantly growing energy demand, grid-connected photovoltaic systems are becoming more and more popular, and many countries have permitted, encouraged, and even funded distributed-power-generation systems. Currently, solar panels are not very efficient with only about $12-20 \%$ efficiency in their stability to convert sunlight to electrical power. The efficiency can drop further due to other factors such as solar panel temperature and load conditions. Every solar panel will have a unique temperature coefficient. Temperature coefficient is important since the temperature of the solar panels has direct influence on the output power produced [2]. Most panels have temperature coefficient of between -0.2 $\% /{ }^{0} \mathrm{C}$ to $-0.5 \% /{ }^{0} \mathrm{C}$ when tested under standard laboratory conditions. The closer the temperature coefficient to zero, the better the panel will perform.

The calculation for the temperature derating is defined by the tested temperature for the panel and its temperature coefficient. The value that will affect the temperature derating is the ambient temperature and the installation type of the panel itself. From the calculation, if the ambient temperature equals to $28^{\circ} \mathrm{C}$ and the installation type is rack, the panel will lose $13.2 \%$ of its output [3]. Studies on the effect of temperature and 
insolation on the performance of the PV panel were developed using PSPICE/MATLAB model and have been presented [4-6].

In order to maximize the power derived from the solar panel, it is important to operate the panel at its optimal power point. Therefore, the power electronics converter interface between a solar panel and a load battery is introduced. The several pulse width modulator (PWM) DC-DC converter is used to extract the maximum power form PV solar panel [7-9]. The conventional of photovoltaic power system may use on-off directly control system. The system has a simple build and structures. However, they also have a significant drawback such as, there is no control applied on the charging state of the battery. The on-off state between the battery and the PV panel cannot provide supply to the load simultaneously and performance power transfer to the load is decreased gradually. From the weakness of the conventional system, the aim of this paper is to present the simple controller in Buck-Boost DC-DC Converter for solving the limiting generation power of PV. For example, ENF 5W 18V Solar PV Module has a value of $18.1 \mathrm{~V}$ at maximum power when there is a high intensity of sunlight [10]. In this case, if the load needed only $12 \mathrm{~V}$ of input, a buck converter in needed. Meanwhile, if the intensity of the sunlight is low, a boost converter is needed to achieve the voltage required by the load.

\section{CONVENTIONAL DC-DC CONVERTER}

Figure 1 shows the several commonly used DC-DC converter circuits such as Buck, Boost and Buck-Boost converters [11-13]. These include switching power MOSFET, diode, inductor and capacitor [14-15].

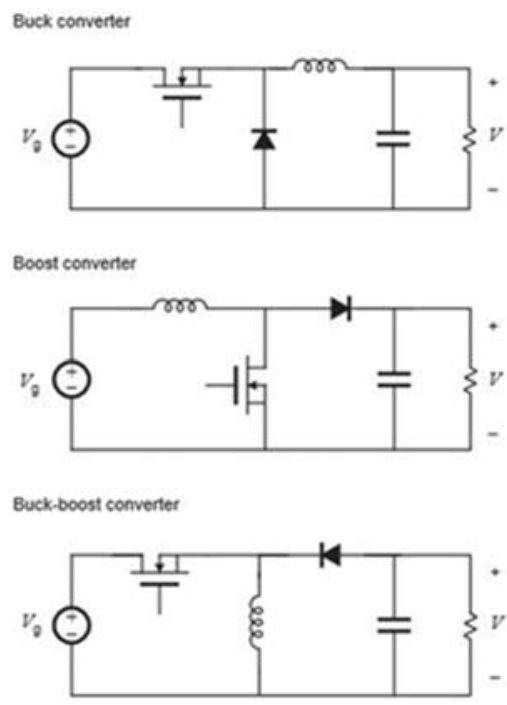

Figure 1. Several basic DC-DC Converter topologies [11]

The voltage level conversion is depending on the circuit topologies by using a volt-second voltage. The dc voltage transfer of boost converter, buck converter and buck-boost converter are expressed in Table 1 . The aim of paper is to control the $12 \mathrm{~V}$ output load for standalone system. In order to control the desired voltage, the parameters of the simulation and hardware are illustrated in Table 2.

Table 1. Converter's equation

\begin{tabular}{cc}
\hline Type of converter & Output voltage equation \\
\hline Buck Converter & $V_{\circ}=D V_{i}$ \\
Boost Converter & $V_{o}=\frac{V_{i}}{1-D}$ \\
Buck-Boost Converter & $V_{o}=-\frac{D V_{i}}{1-D}$ \\
\hline
\end{tabular}

Table 2. Parameters used

\begin{tabular}{cc}
\hline Parameters & Value \\
\hline Load voltage, $V_{\text {load }}$ & $12 \mathrm{~V}$ \\
Battery voltage, $V_{\text {bat }}$ & $6 \mathrm{~V}$ \\
Load, $R_{\text {load }}$ & $100 \Omega$ \\
PV panel voltage, $V_{\text {solar }}$ & 0 to $18 \mathrm{~V}$ \\
\hline
\end{tabular}




\subsection{Buck Converter}

The output from the solar panel is buck or reduce by using a buck converter. The output voltage from the solar panel is fed to the MOSFET. When MOSFET is on, the current will flow from load through the inductor. Inductor starts building up oscillations by developing magnetic field across it and causes the voltage to be reduced. When MOSFET is off, electromotive force (EMF) is suddenly reversed in the inductor that opposes further drop in current. The configuration used for the simulation of buck is shown in Figure 2.

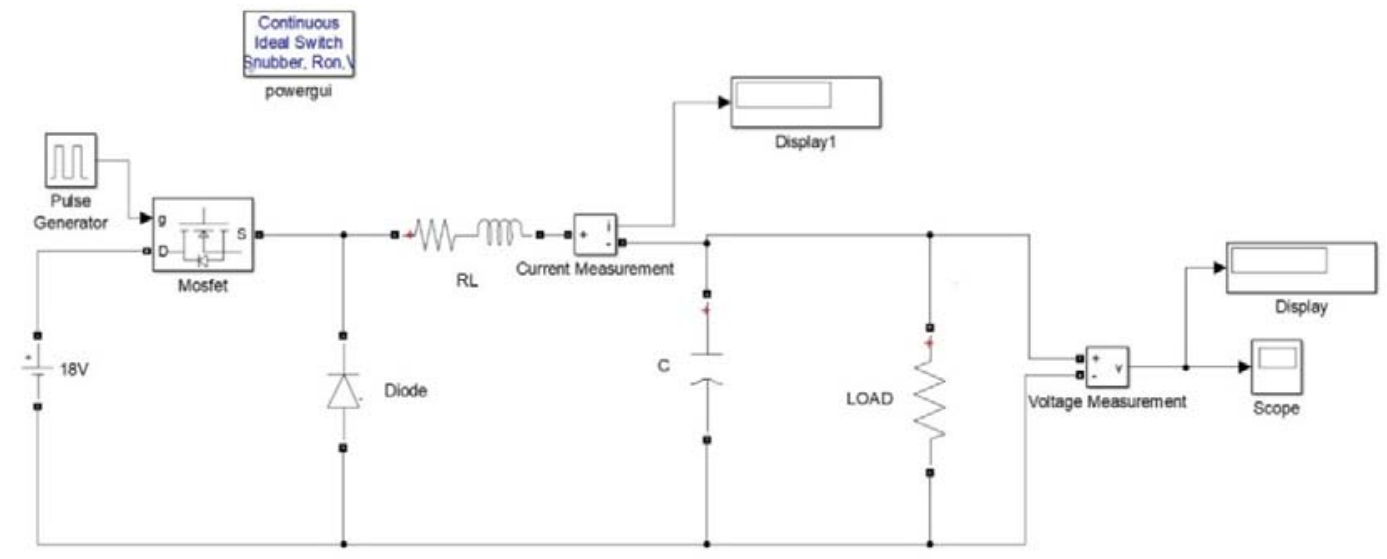

Figure 2. Buck converter configuration

In this simulation, the PV panel value is set to be at $18 \mathrm{~V}$ with the converter switching frequency of $10 \mathrm{kHz}$. The duty ratio for the simulation is $66.67 \%$. The output of the input voltage is halved because of the $66.67 \%$ duty cycle. Figure 3 shows the output voltage waveform.

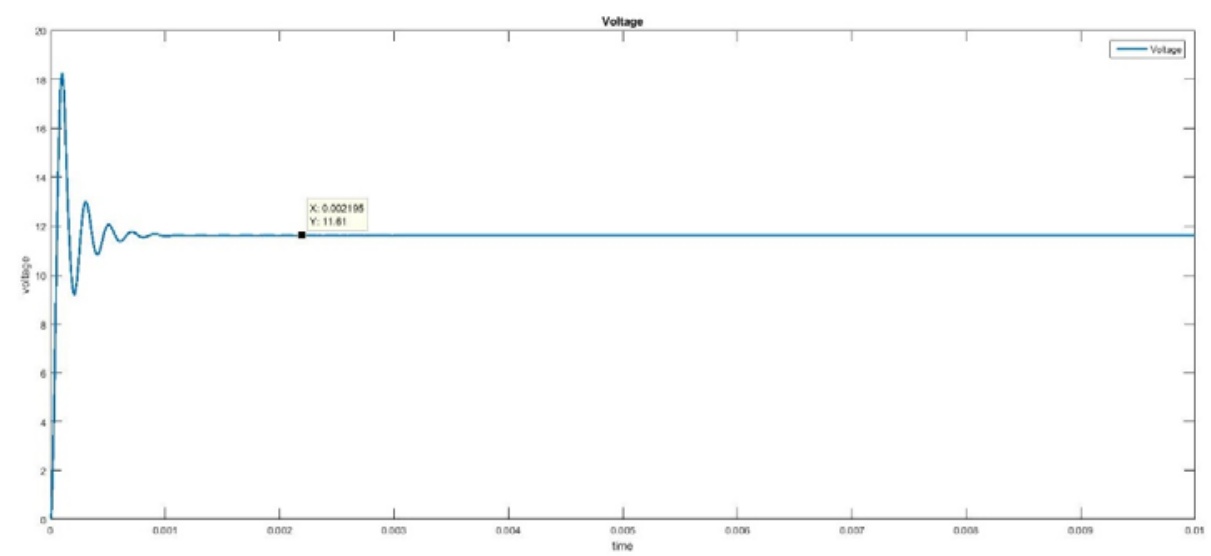

Figure 3 Buck output waveform

From Figure 3, the value of the output voltage from the PV panel is $18 \mathrm{~V}$. This simulation shows that the input voltage had been reduced to $11.61 \mathrm{~V}$ from its original value by using buck converter. Buck converter capability to reduce voltage is good for integrating it with a PV system. More stable and suitable voltage level can be obtained but it cannot provide a voltage desired if the performance of the PV panel is poor during cloudy weather. The calculated efficiency of buck converter is $96 \%$. 


\subsection{Boost Converter}

The arrangement of the component for boost converter is different as shown in Figure 4.

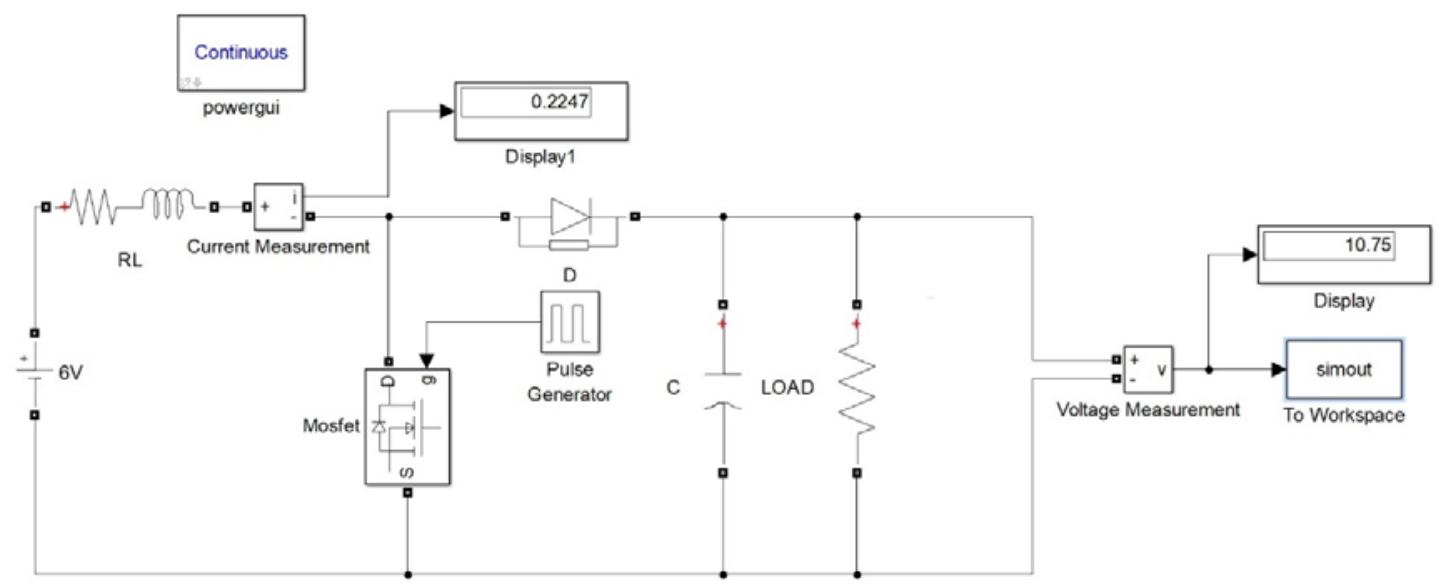

Figure 4. Boost converter configuration

Boost converter is used to step up the voltage. The output voltage from the converter is controlled by varying the duty cycle. Current flow via inductor and MOSFET. The energy stored in the magnetic field across the inductor and there is no current flowing through diode. The load is supplied by the capacitor. When MOSFET is turned off, inductor current opposes by immediately reversing EMF. The inductor voltage adds with the source voltage and thus boosting the voltage.

In this simulation, the source is set as a $6 \mathrm{~V}$ battery with the converter switching frequency of $10 \mathrm{kHz}$. The duty ratio of the simulation is $31.5 \%$. The output voltage obtained from the simulation is doubled the input voltage value. Figure 5 shows the waveform of the output voltage.

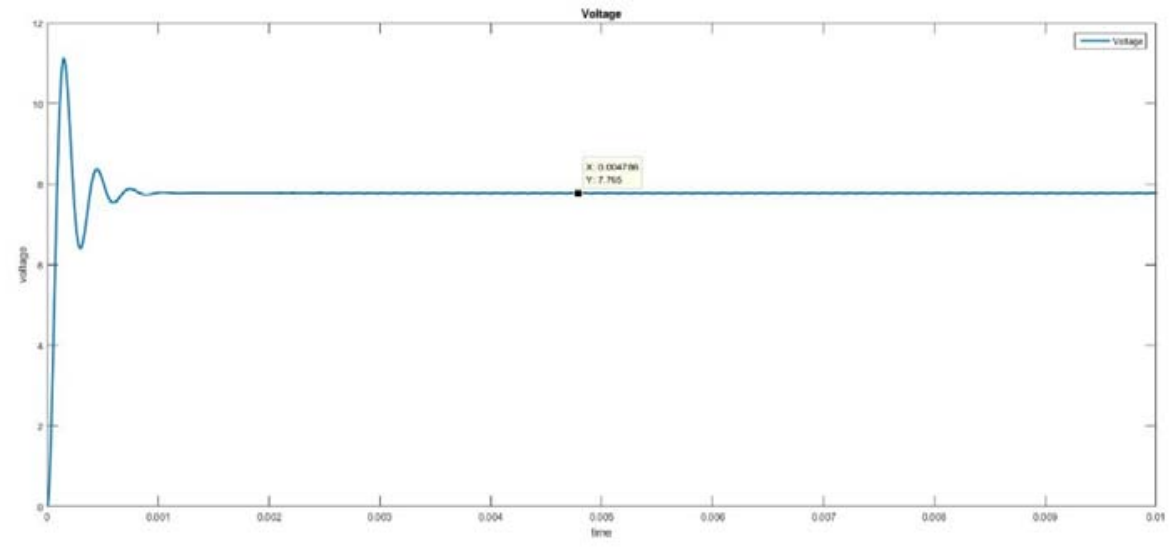

Figure 5. Boost output waveform

From Figure 5, the value of the output voltage is $7.793 \mathrm{~V}$. This simulation shows that the input voltage has been increased by the converter. Boost converter can boost the voltage from PV panel even on cloudy weather. The capability to step up the voltage is very much needed in renewable energy such as solar which the intermittency issue is a big deal. The drawback of a boost converter is that it only can step up but cannot step down the voltage level. Boost converter efficiency that was calculated is $43.53 \%$. 


\subsection{Buck-Boost Converter}

The configuration for Buck-Boost converter is shown in Figure 6.

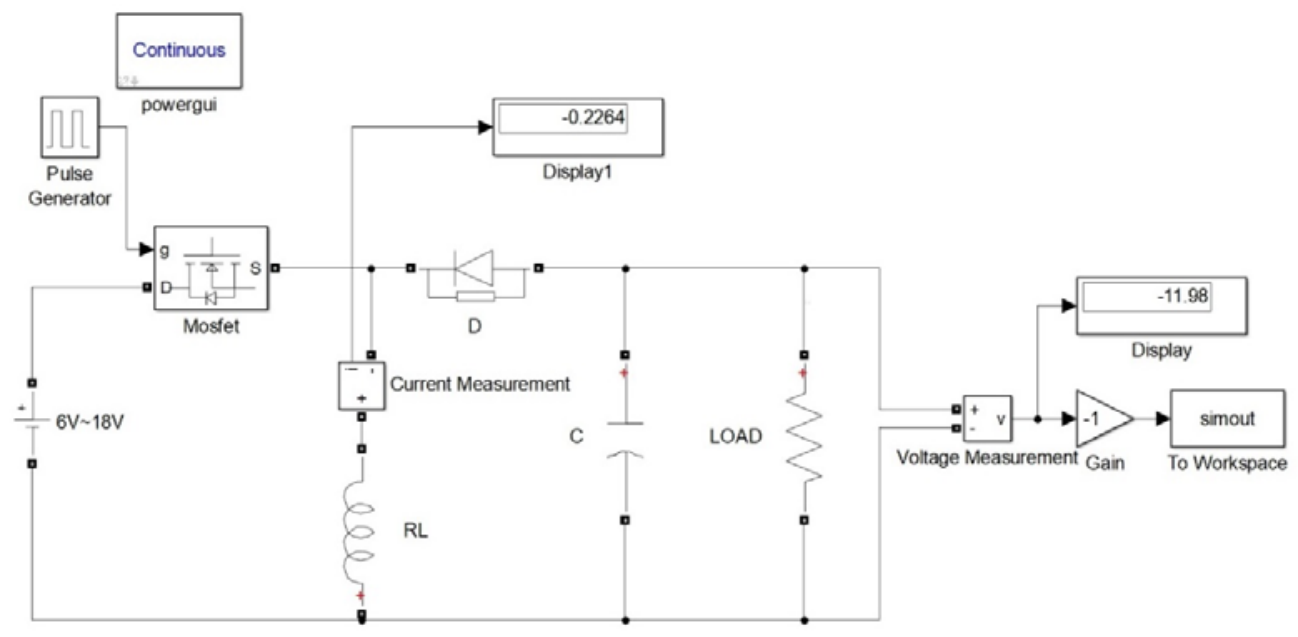

Figure 6. Buck-Boost converter configuration

In this converter, the voltage can be either increased or decreased. It is all depending on the duty cycle. Inductor is directly store energy by developing magnetic field when MOSEFT is on. Because of the diode is reversed biased, there is no current flow to the load. Capacitor works during this time. When MOSFET is turned off, inductor is disconnected form the source. It opposes current to drop instantly by reversing the EMF. The step-up duty ratio is above 50\% meanwhile, the step-down duty ratio is below $50 \%$.

In this simulation, the PV panel is set from $6 \mathrm{~V}$ to $18 \mathrm{~V}$ with the converter switching frequency of 10 $\mathrm{kHz}$. Two simulation is done with the different of duty cycle ratio.

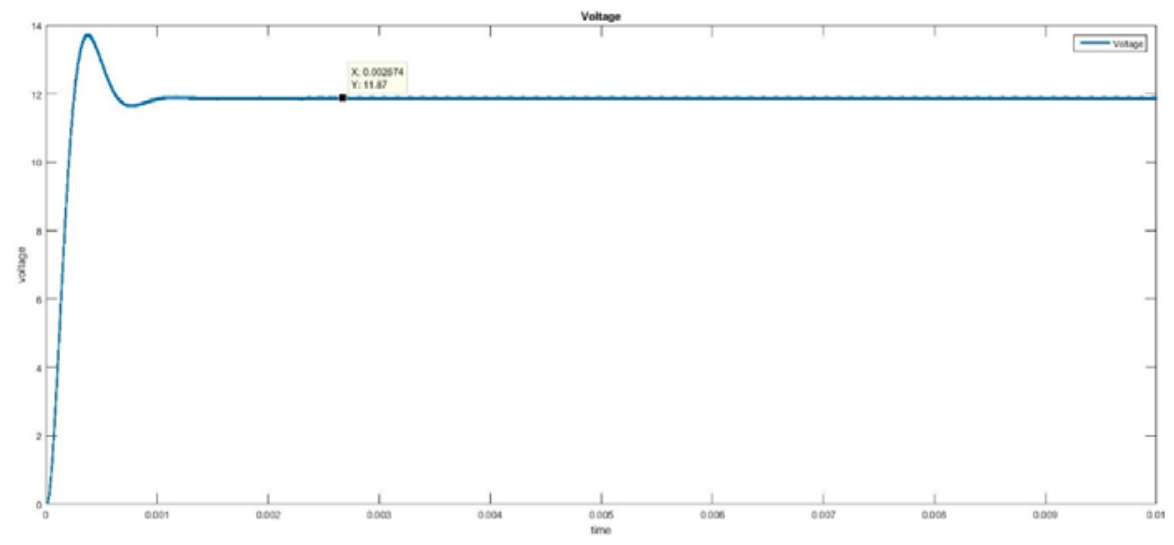

Figure 7. Output voltage waveform when duty cycle is $68 \%$.

Figure 7 shows the output voltage obtained when the duty cycle is $68 \%$. The value of the output voltage is boosted up from $6 \mathrm{~V}$ to $11.91 \mathrm{~V}$. 


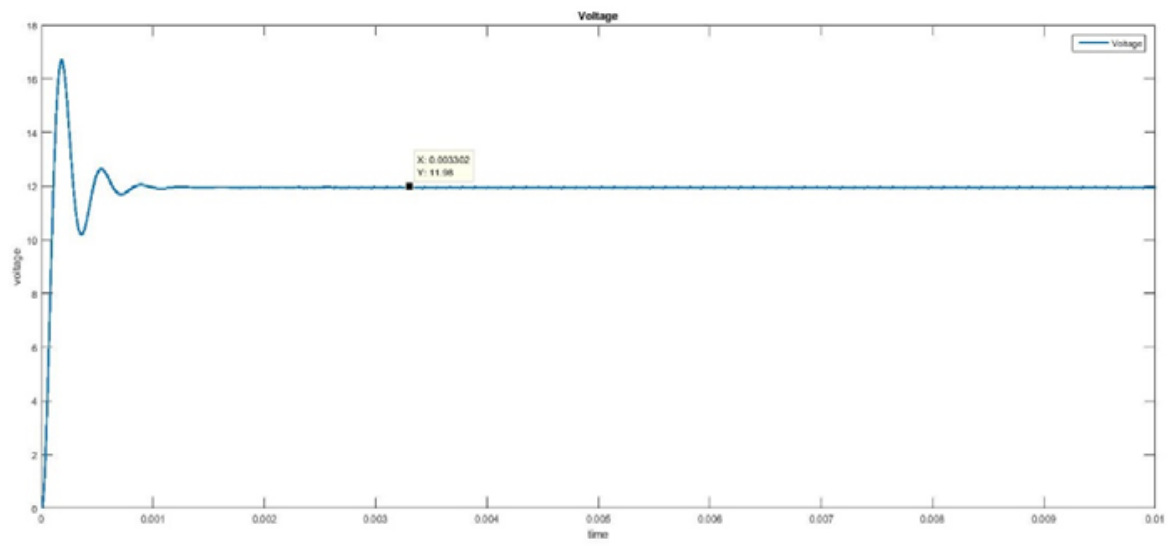

Figure 8. Output voltage waveform when duty cycle is $41.5 \%$

Figure 8 shows the output voltage obtained when the duty cycle is $41.5 \%$. The value is bucked from $18 \mathrm{~V}$ to $11.98 \mathrm{~V}$. From both simulations, it shows that Buck-Boost converter is capable to either decrease or increase the input voltage.

Buck-Boost converter is different than buck converter or boost converter. It capable to step up or step down the voltage level. It is very much suitable for renewable energy application. The efficiency for this converter when in buck operation is $27.93 \%$ while in boost operation, the efficiency is $9.13 \%$. The three converter that were simulated before can provide a regulated voltage level needed for PV system. However, each of them has their own drawback that will suffice the efficiency of a PV system application. Table 3 shows the summarization of the simulation.

Table 3. Summarization of the converters.

\begin{tabular}{cccc}
\hline Type of converter & Capability of regulating voltage & Availability for secondary supply & Efficiency \\
\hline Buck Converter & Step-down only & N/A & $96 \%$ \\
Boost Converter & Step-up only & N/A & $26.75 \%$ \\
Buck-Boost Converter & Step-up and step-down & & Buck $=27.93 \%$ \\
& & & Boost $=9.13 \%$ \\
\hline
\end{tabular}

From Table 3, each of the converter that were simulated is not suitable for placing a secondary supply in the system. The secondary supply such as the battery is important to provide a higher efficiency system. For example, battery is capable to provide a very much needed supply for the load in case where the PV panel are not capable to provide one.

The efficiency is satisfying even though to the limited capability of the conventional converter. Eventhough the efficiency for the buck converter is high which is $96 \%$, it still only for stepping down the voltage and cannot steup-up it since its only a buck converter. The conventional solution is to manually change the buck converter to boost converter. The temperature derating issue adds up the efficiency lacks in using the conventional converter. Buck-Boost DC-DC Converter is capable to overcome these issues. The converter can provide power flow when using the PV system. In the viewpoint of efficiency, the only problem that will be left is the temperature derating if other issue can be solve by using the converter.

\section{PROPOSED SYSTEM}

Figure 9 shows on how the mode of the Buck-Boost DC-DC Converter will operates in this system. As shown in the figure, the converter is the centerpiece between all the three main block which are the PV panel, the battery and the load. PV panel is place on the high voltage side while the battery is placed on the low voltage side. Power flow is shown with the operating mode of the converter which are the buck mode and the boost mode. Buck mode is where the power flow from the PV panel to the load and the battery. Boost mode is where the power flow from the battery to the load. 


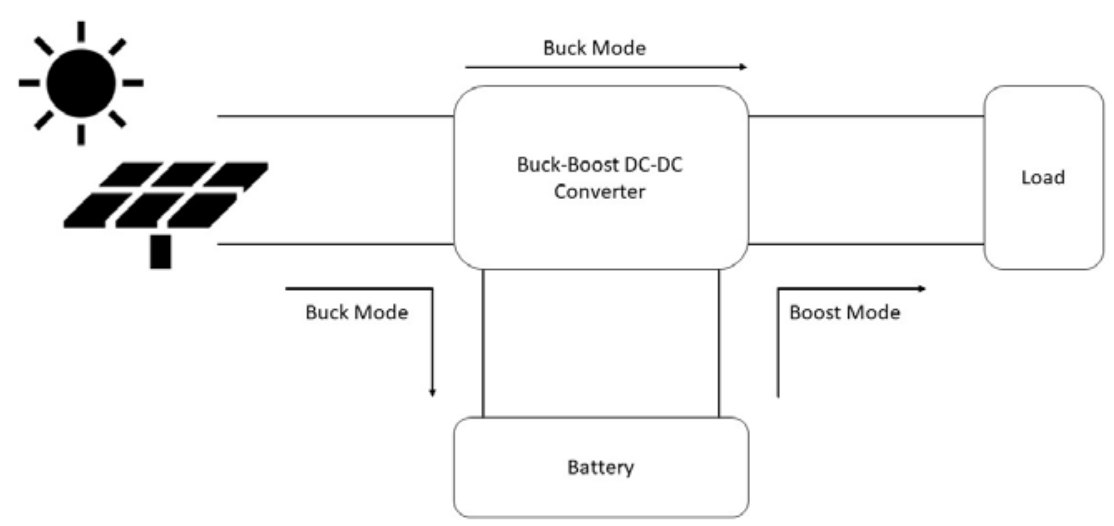

Figure 9. Buck-Boost Converter operation diagram

\subsection{Converter circuit topology}

Figure 10 shows the Buck-Boost Converter circuit topology. The high voltage side is connected to the PV panel while the low voltage is connected to the battery. This circuit is a "'boost-type" since the battery is placed on the low voltage side [16]. Both will be modelled as a source with equivalent series impedance. This circuit consist of two IGBTs as a switch, an inductor and a capacitor

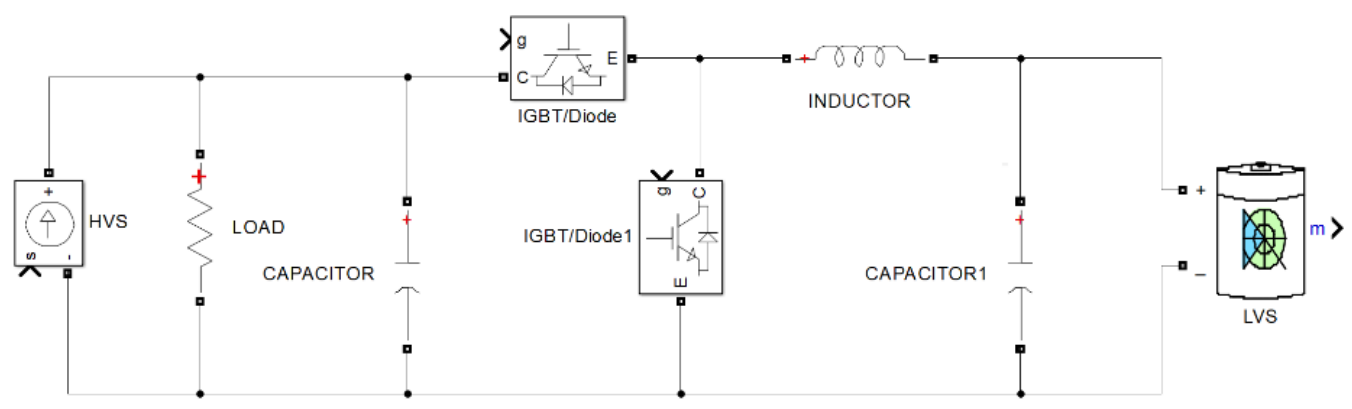

Figure 10. The proposed Buck-Boost Converter

The converter operates in two modes and it is defined according to the voltage sense at the load. The two modes are buck mode and boost mode. For the buck mode, IGBT is the main switch and IGBT1 is the auxiliary switch with Diode1 acting as the freewheel diode. For the boost mode, IGBT1 is the main switch and IGBT is the auxiliary switch with Diode act as the freewheel diode.

In the system, there are two power sources: PV panel and the battery. Therefore, the converter needs to manage two sources to ensure the whole system operates with high efficiency and high reliability. The managing mode of the converter is defined by directly comparing the voltage value sensed at the load with the reference voltage. The voltage chosen for the load is $V_{\text {load }}=12 \mathrm{~V}$ so, the reference voltage is $V_{\text {ref }}=$ $12 \mathrm{~V}$. A voltage sensing device is placed in parallel to the load to obtain the real-time reading of the load voltage. If $V_{\text {load }}<V_{\text {ref }}$, the converter will operate in boost mode and the battery need to be discharge to the load. The battery power will flow through the converter and boosted to the desired voltage level of the load which is $12 \mathrm{~V}$. This shows the condition where the PV panel is not capable to supple the load. If $V_{\text {load }} \geq V_{\text {ref }}$, the converter will operate in buck mode. The PV panel voltage is bucked to $12 \mathrm{~V}$ for supplying the load voltage. This condition shows that the PV panel is capable to supply the load and the battery is not needed in this mode. The residual power that flows through the buck will also go into the battery and charging operation is online. Table 4 summarize the mode and condition of the converter.

Int J Pow Elec \& Dri Syst, Vol. 10, No. 2, June 2019 : 1090 - 1101 
Table 4. Operation modes of the Buck-Boost Converter

\begin{tabular}{cc} 
Conditions & Converter Mode \\
\hline$V_{\text {load }}<V_{\text {ref }}$ & Boost Mode \\
$V_{\text {load }} \geq V_{\text {ref }}$ & Buck Mode \\
\hline
\end{tabular}

\subsection{PWM for the IGBTs}

The IGBT are used in this converter and they need a gate signal to perform the switching operation. The switching operation is for either buck or boost. The load voltage that was measured is compared to the reference voltage and hence, will produce error voltage. The error voltage is then fed to the PI controller as shown in Figure 12.

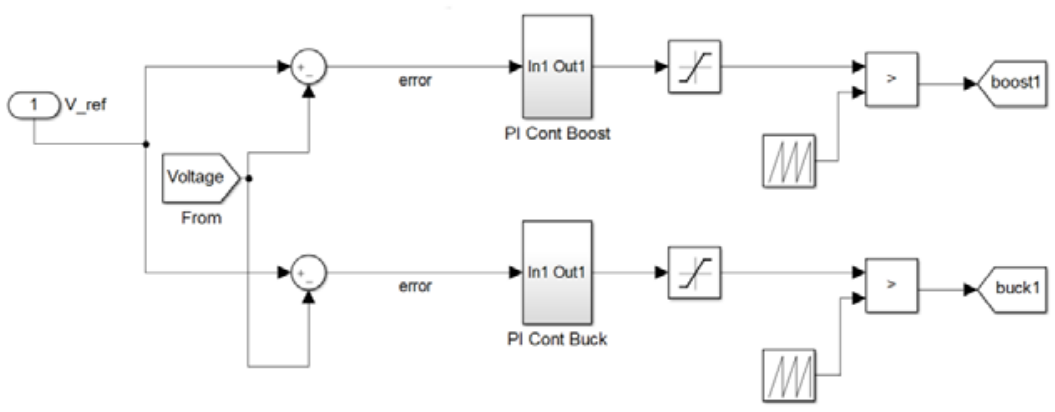

Figure 11. Error network and PWM generator for the converter

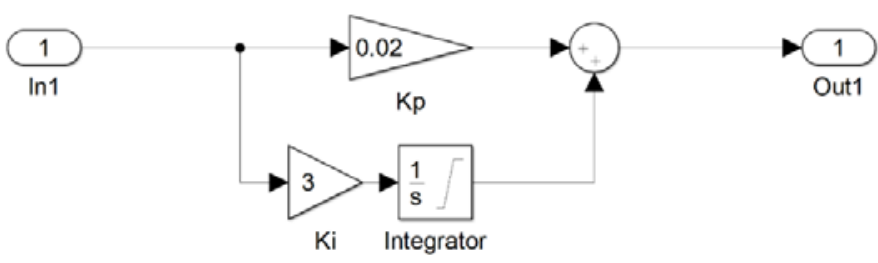

Figure 12. PI controller

PI controller is used in this operation to translate the error voltage into a value range from 0 to 1 . This is because the error voltage is needed to be compared with the sawtooth waveform in order to produce the PWM signal for the IGBTs.

\subsection{Mode selection control}

The converter works in two mode that is defined by comparing the voltage measured at the load with the reference voltage. In order to implement the power flow, the reference voltage and measured voltage must be compared and it will decide the mode of the converter. The deciding operation is shown in Figure 13. The voltage at the load is measured. Since the load is supposed to be at $12 \mathrm{~V}$, so the reference voltage is also set to $12 \mathrm{~V}$. When operating, the reference voltage is compared with the measured voltage. In simulation, a comparator block is used and the result of the comparison is either 1 or 0 . The compared result will go to two switch blocks. Both of this switch block will decide the mode of the converter. 


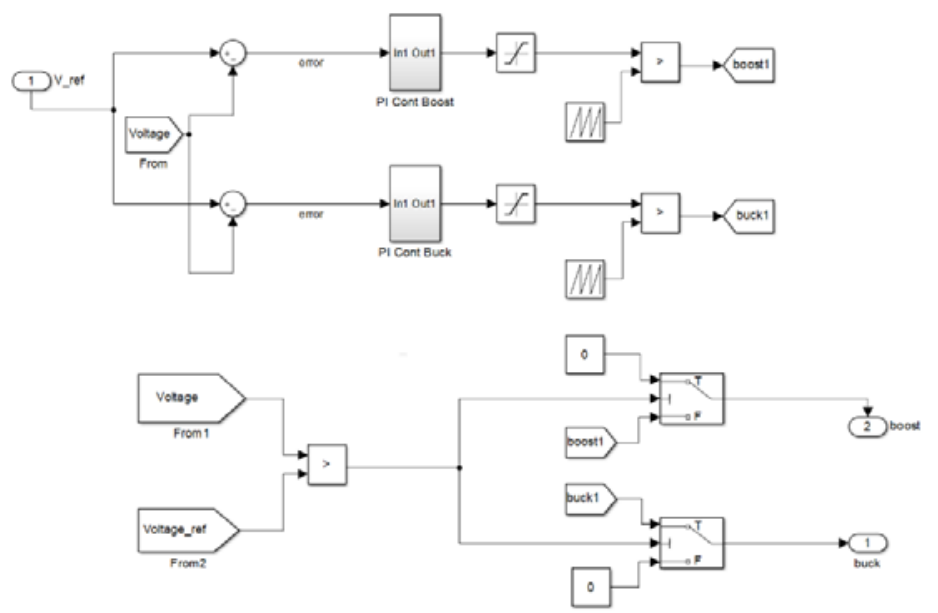

Figure 13. Mode decider of the controller.

\section{SIMULATION AND RESULTS}

The simulation of the system is simulated by using Matlab Simulink software [17]. Figure 14 shows the full schematic of the simulation.

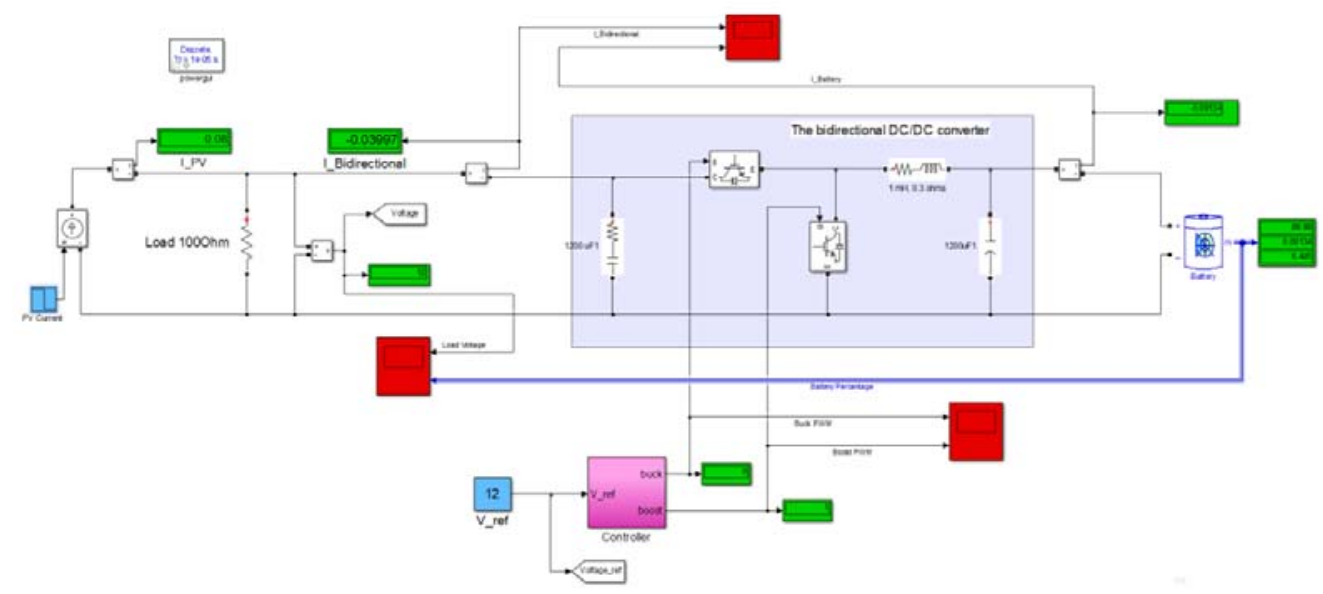

Figure 14. Buck-Boost Converter system simulation using Matlab Simulink.

The PV panel is represented using a controlled current source block available in the Simulink library. It represents the current of the PV panel in terms of current ampere. The controlled current source is placed on the high voltage side. The value of the PV current is varied using two value to represent the unbalance state of PV panel in real life. In this case, the values are $0.08 \mathrm{~A}$ and $0.16 \mathrm{~A}$. These two values show the capability of the PV panel to supply the load.

The battery is placed on the low voltage side. The rating of the battery used for this simulation is $6 \mathrm{~V}$. The percentage of the battery is also varied in form of two conditions. The conditions of the battery are $90 \%$ (good condition) and 30\%(poor condition).

Buck-Boost Converter is placed between the two-power source and the power flow will transfer in direction. By placing the load in between the PV panel and the converter will create a fraction in current. The divided current will go to the load and the converter. By dividing the current, a voltage that desired at the load can be maintained while the residual current can charge the battery. The parameter used for this simulation are summarized in the Table 5.

Int J Pow Elec \& Dri Syst, Vol. 10, No. 2, June 2019 : 1090 - 1101 
The main objective of simulating the system is to test the capability of the converter to make the power flow. Besides that, the reliability of the controller to decide the mode of the converter also need to be validated. The simulations are done with various condition of the PV panel and the capacity of the battery. This is to show the real state of these sources in daily usage. The conditions are listed in Table 6.

Table 5. Parameter used for the simulation

\begin{tabular}{cc}
\hline Parameters & Value \\
\hline Load voltage, $V_{\text {load }}$ & $12 \mathrm{~V}$ \\
Battery voltage, $V_{\text {bat }}$ & $6 \mathrm{~V}$ \\
Load, $R_{\text {load }}$ & $100 \Omega$ \\
PV panel voltage, $V_{\text {solar }}$ & 0 to $18 \mathrm{~V}$ \\
Simulation time, $T_{S}$ & $10 \mathrm{~s}$ \\
\hline
\end{tabular}

Table 6. Conditions for the simulation

\begin{tabular}{cc}
\hline State of the PV panel $(V)$ & Capacity of the battery (\%) \\
\hline$V_{\text {solar }}>V_{\text {ref }}$ & $90 \%$ \\
$V_{\text {solar }}<V_{\text {ref }}$ & $90 \%$ \\
$V_{\text {solar }}>V_{\text {ref }}$ & $30 \%$ \\
$V_{\text {solar }}<V_{\text {ref }}$ & $30 \%$ \\
\hline
\end{tabular}

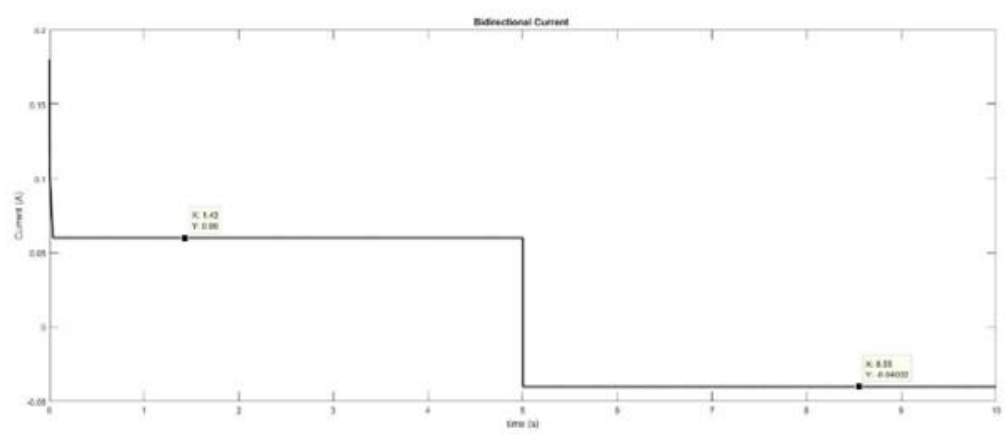

Figure 15. Inductor current
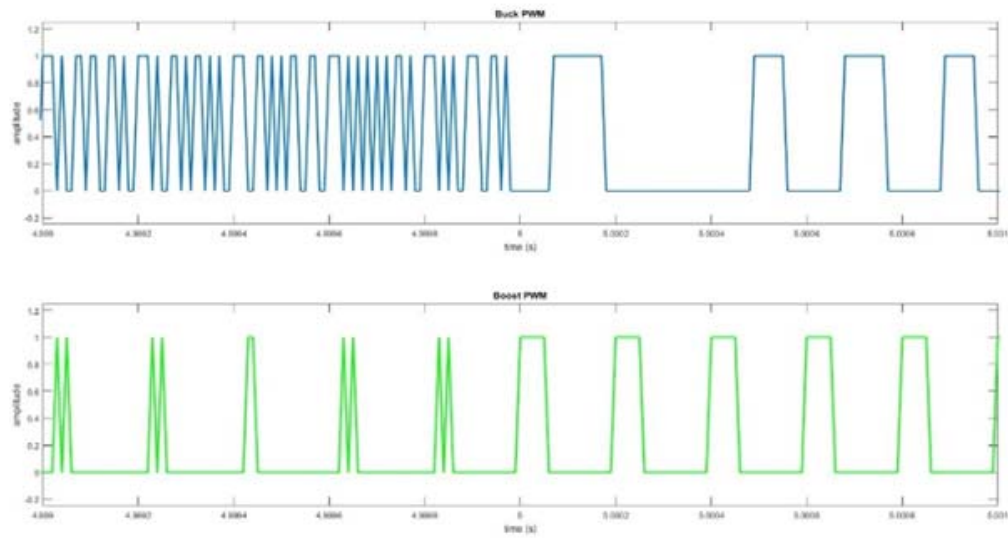

Figure 16. PWMs waveform.

Figure 15 shows the waveform of the current flowing through the converter. For the first 5 second, the PV panel voltage is higher than the reference voltage which means that it capable to provide supply power to the load so, the current is positive. The current is flown from the PV panel to the load and the battery. From Figure 16, the PWM for buck is much more frequent than the PWM for the boost. After 5 second, the PV panel voltage is less than the reference voltage, the battery now is the main supply. The current become negative because the direction of the current flow is reversed form the battery to the load. In Figure 16, the boost PWM are more frequent after 5 second.

Within these conditions, the load voltage is maintained at desired value which is at $12 \mathrm{~V}$. The battery is in charging state within the first 5 second and discharging for the rest of the simulation. The same results 
are also obtained for the second simulation where the battery capacity is at $30 \%$. It shows that even though the battery is low, it still capable of charging and discharging accordingly. Table 7 summarize the simulation results.

Comparison can be made with the result of the conventional converter obtain in Table 3 in the previous topic. The proposed converter is capable to operate and gave out $12 \mathrm{~V}$ no matter the state of the input. This dynamic performance is not provided from the conventional converter. Besides that, the proposed converter also provides a charging solution to the battery.

Table 7. Summarized results.

\begin{tabular}{cccc}
\hline Condition of the PV Panel $(V)$ and Capacity of the Battery (\%) & Voltage at the load, $(V)$ & $\begin{array}{c}\text { Mode of the } \\
\text { Converter }\end{array}$ & $\begin{array}{c}\Delta \% \text { Battery } \\
\text { Capacity }\end{array}$ \\
\hline $\begin{array}{c}V_{\text {solar }}>V_{\text {ref }} \\
\text { Battery at } 90 \% \\
V_{\text {solar }}<V_{\text {ref }} \\
\text { Battery at } 90 \% \\
V_{\text {solar }}>V_{\text {ref }}\end{array}$ & $12 \mathrm{~V}$ & Buck mode & Increase \\
Battery at $30 \%$ & $12 \mathrm{~V}$ & Boost mode & Decrease \\
$V_{\text {solar }}<V_{r e f}$ & $12 \mathrm{~V}$ & Buck mode & Increase \\
Battery at $30 \%$ & $12 \mathrm{~V}$ & Boost mode & Decrease \\
\hline
\end{tabular}

\section{CONCLUSIONS}

Buck-Boost DC-DC Converter is a next step in converting renewable energy sage in daily life to user requirement. Conventional converter can do such operation but it only can transfer power in one direction. Buck-Boost DC-DC Converter can provide a power flow thus, can increase the power usage efficiency. In this report, the objectives to design the converter is achieved by confirming the results obtained in the simulation and hardware.

\section{ACKNOWLEDGEMENTS}

The author would like to thank the Universiti Teknikal Malaysia Melaka for supporting this work under research grant PJP/2018/FKE(6B)/S01607.

\section{REFERENCES}

[1] Pukhrem Shivananda, "Types Of Power Converters In A PV System -," 2014. [Online]. Available: http://solarlove.org/types-power-converters-pv-system/. [Accessed: 14-Nov-2017].

[2] K. Robinson, "What is the temperature coefficient of a solar module? - Sinovoltaics - Your Solar Supply Network," SINO VOLTAICS, 2017. [Online]. Available: http://sinovoltaics.com/learning-center/testing/what-is-thetemperature-coefficient-of-a-solar-module/. [Accessed: 12-Jul-2018].

[3] "Solar Panel Temperature | Effect on performance," 2018. [Online]. Available: https://solarcalculator.com.au/solarpanel-temperature/. [Accessed: 17-Feb-2018].

[4] J. A. Gow and C. D. Manning, "Development of a photovoltaic array model for use in power-electronics simulation studies," IEE Proc. - Electr. Power Appl., vol. 146, no. 2, p. 193, 1999.

[5] H. Patel and V. Agarwal, "MATLAB-Based Modeling to Study the Effects of Partial Shading on PV Array Characteristics," IEEE Trans. Energy Convers., vol. 23, no. 1, pp. 302-310, Mar. 2008.

[6] M. G. Villalva, J. R. Gazoli, and E. R. Filho, "Comprehensive Approach to Modeling and Simulation of Photovoltaic Arrays," IEEE Trans. Power Electron., vol. 24, no. 5, pp. 1198-1208, May 2009.

[7] T. A. Bosco Raj et al., "Grid Connected Solar PV System with SEPIC Converter Compared with Parallel Boost Converter Based MPPT," Int. J. Photoenergy, vol. 2014, pp. 1-12, Mar. 2014.

[8] N. H. Baharudin, T. Muhammad, N. Tunku, and F. A. Hamid, "Topologies of DC-DC Converter in Solar PV Applications," Indones. J. Electr. Eng. Comput. Sci., vol. 8, no. 2, pp. 368-374, 2017.

[9] V. C. Kotak, P. Tyagi, and A. Professor, "DC To DC Converter in Maximum Power Point Tracker," Int. J. Adv. Res. Electr. Electron. Instrum. Eng. (An ISO Certif. Organ., vol. 3297, no. 12, 2007.

[10] "WSL Solar | 5W 18V solar PV module | Solar Panel Datasheet | ENF Panel Directory.” [Online]. Available: https://www.enfsolar.com/pv/panel-datasheet/Polycrystalline/18005. [Accessed: 19-Jul-2018].

[11] J. G. Webster, "Wiley Encyclopedia of Electrical and Electronics Engineering," 1999.

[12] A. Fathah, "Design of a Boost Converter." 2013.

[13] J. Ejury, "Buck Converter Design," 2013.

[14] C. Sharma and A. Jain, "Simulation of buck, boost and buck- boost power converters for solar," no. September, 2014.

[15] T. Agarwal, "Transistors - Major Difference between BJT and MOSFET," EL-PRO-CUS, 2016. [Online]. 
Available: https://www.elprocus.com/difference-between-bjt-and-mosfet/. [Accessed: 12-Jul-2018].

[16] J.-S. Lai and D. J. Nelson, "Energy Management Power Converters in Hybrid Electric and Fuel Cell Vehicles," Proc. IEEE, vol. 95, no. 4, pp. 766-777, Apr. 2007.

[17] “Simulink ${ }^{\circledR}$ Getting Started Guide R2018b,” 1990.

\section{BIOGRAPHIES OF AUTHORS}

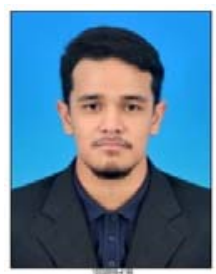

M. Z. Zulkifli was born in Penang, Malaysia in 1994. He received Diploma in Electrical Engineering in 2015 and Bachelor's in Electrical engineering in 2018 from the same institution which is Universisti Teknikal Malaysia Melaka. He is currently pursuing his studies for Master of Electrical Engineering. His are of interest is in power electronics.

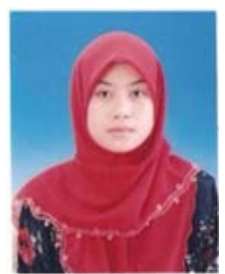

M. Azri was born in Malacca, Malaysia, in 1977. She received her B.Eng (Hons) Electrical degree from University Technology Mara, Shah Alam, Malaysia and the M.Sc. (Electrical Power Engineering) degree from the University Putra Malaysia, Serdang, Malaysia in 2001 and 2004 respectively. She is received her Ph.D. degree at the UM Power Energy Dedicated Advanced Center (UMPEDAC), University of Malaya, Kuala Lumpur, Malaysia in 2014. She is a senior lecturer and currently a Head Department of Power Electronics and Drives, Fakulti Kejuruteraan Elektrik. She is a member of IET. Her research interests include power electronics and renewable energy.

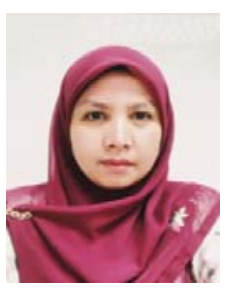

A. Alias was born in Terengganu, Malaysia, in 1978. She received her B. Eng in Electrical (Control and Instrumentation) (Hons) and M. Eng (Electrical) from the Universiti Teknologi Malaysia, in 2000 and 2003, respectively, and her PhD from University of Malaya in 2015. She is a senior lecturer at the Faculty of Electrical Engineering, Universiti Teknikal Malaysia Melaka (UTeM). Her main research interests are in modeling, control systems analysis and power electronics application engineering systems

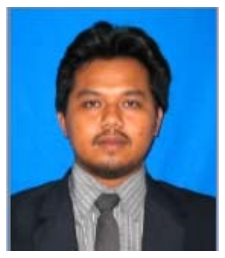

Md. H. N. Talib was born in Malaysia, in 1976. He received his B.S. in Electrical Engineering from the Universiti Teknologi Malaysia (UTM), Johor, Malaysia, in 1999, M.S. in Electrical Engineering from the University of Nottingham, Nottingham, UK, in 2005 and $\mathrm{PhD}$ from the Universiti Teknikal Malaysia Melaka (UTeM), Malaysia in 2016. He is currently a senior lecturer at UTeM. His main research interests include power electronics, fuzzy logic control and motor drives.

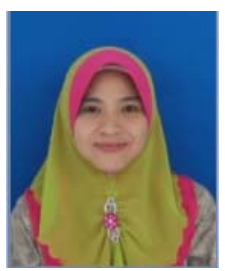

Jurifa binti Mat Lazi received her bachelor's degree in Electrical Engineering from Universiti Teknologi Malaysia in 2001. She then obtained his Master of Science degree in Electrical Power Engineering from University Universiti Teknologi Malaysia, in 2003. She received his Ph.D degree from University Universiti Teknikal Malaysia Melaka in 2016. She has served as an academic staff at Universiti Teknikal Malaysia Melaka (UTeM) since 2001 and she is currently a senior lecturer and Head of Industrial Training Coordinator in the Faculty of Electrical Engineering, UTeM. Her research interests include Machine Drives especially in Sensorless and PMSM drives, Power Electronics and Power System. 